LIST OF REVIEWERS 2018-2019

\section{MANUSCRIPT FORMAT}

All electronic files should be composed in a word processing format. Manuscripts received by ASK that do not adhere to these guidelines may be, at the discretion of the Editor, rejected without further review.

Text must be double spaced with margins of $2,5 \mathrm{~cm}$ (1 inch), and page size A4. Manuscripts in 'Letter' size ( 8.5 by 11 inch) should not be used. Use a proportional typeface font, like 'Times New Roman', 12-point size. The length of the manuscript should not exceed 8,000 words.

Tables must be consecutively numbered: $1,2,3, \ldots$ The title of each table should briefly and accurately identify its content and must be unique for each table. Column headings should be as short as possible. All relevant and important information (e.g. sample size) should be submitted in a note below the table or noted clearly in the text under an easily identifiable heading. Footnotes to table cells should be marked with lower case letters: $a, b, c, \ldots$ Footnotes indicating the significance level should use asterisks (not letters). Each table should start from a new page.

Charts and graphics may be developed under any software and then embedded as picture objects into the manuscript. All charts must be titled and numbered as Figure 1, Figure 2, etc. Place all tables and charts at the end of document and provide clear references to them in the text.

Except in tables, charts and graphs, ASK prefers endnotes to footnotes. Endnotes should be collected after the end of the text, before the references. We remind you to limit the number of footnotes and endnotes.

The references format should follow the ASA style (www.asanet.org/). For more information, please see the website for ASK (www.AskResearchAndMethods.org). Please attach the DOI numbers, if available.

\author{
Joerg Blasius \\ Szymon Czarnik \\ Kaja Gadowska \\ Agata Gąsiorowska \\ Paweł Grygiel \\ Piotr Kocyba \\ Michał Kotnarowski \\ Joanne Lefeldt \\ Katharina Loter \\ Alla Marchenko \\ Katharina Meitinger \\ Laura Naegele \\ Natalia Otrishchenko \\ Artur Pokropek \\ Kevin Reuning \\ Krzysztof Stachura \\ Agata Stanisz \\ Gordon Willis \\ Katerina Vrablikova \\ Olga Zelinska
}




\section{ASK: RESEARCH AND METHODS}

\section{E-ISSN 2544-0799}

ISSN 1234-9224

Ask: Research and Methods is an open access journal

co-published by The Ohio State University Libraries and

the Institute of Philosophy and Sociology, Polish Academy

of Sciences. ASK is a peer-reviewed journal devoted to

the methodology of social science research. ASK welcomes

articles on a broad range of topics, including conceptualization

and measurement, survey methods, quantitative and qualitative

data analysis, data archiving and research ethics.

This volume of ASK: Research and Methods is financed by funds allocated

by the Ministry of Science and Higher Education for the dissemination of knowledge [DUN].

\section{EDITORS}

EDITOR IN CHIEF: Henryk Domański (Polish Academy of Sciences)

EDITORIAL ADVISER: Jolanta Perek-Białas (Jagiellonian University and Warsaw School

of Economics)

METHODOLOGICAL ADVISERS: Paweł B. Sztabiński (Polish Academy of Sciences) and

Mateusz Halawa (Polish Academy of Sciences)

STATISTICAL ADVISERS: Zbigniew Sawiński (Polish Academy of Sciences) and

Piotr Jabkowski (Adam Mickiewicz University)

DIGITAL CONTENT AND PUBLISHING ADVISERS: Colin Odden (The Ohio State University)

and Joshua K. Dubrow (Polish Academy of Sciences and The Ohio State University)

LANGUAGE EDITOR: Stephen Davies

MANAGING EDITOR: Małgorzata Łukianow (Polish Academy of Sciences)

\section{EDITORIAL BOARD}

Jan Falkowski, Warsaw University

Jarosław Górniak (Jagiellonian University)

Achim Koch (GESIS - Leibniz Institute for the Social Sciences, Mannheim)

Daniel H. Krymkowski (University of Vermont)

Robert M. Kunovich (University of Texas at Arlington)

Sheri Kunovich (Southern Methodist University)

Grzegorz Lissowski (University of Warsaw)

Sandra Marquart-Pyatt (Michigan State University)

Bart Meuleman (KU Leuven)

Małgorzata Mikucka (Université Catholique de Louvain)

Kazimierz M. Słomczyński (The Ohio State University and Polish Academy of Sciences)

Franciszek Sztabiński (Polish Academy of Sciences)

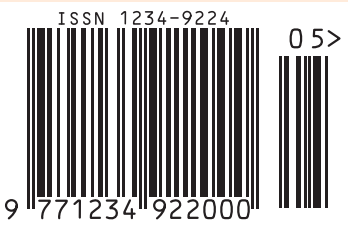

